Environment Conservation Journal 15(1 \& 2) 191-193, 2014

ISSN 0972-3099 (Print) 2278-5124 (Online)

Abstracted and Indexed

\title{
A preliminary study on lichen diversity of Kailash and its environs, Bhaderwah, J\&K.
}

\author{
Sachin Sharma ${ }^{1}$, Anil K. Raina ${ }^{1} \bowtie{\text { and D.K. } \text { Upreti }^{2}}^{2}$
}

Received: 12.03.2014

Accepted: 17.05.2014

\begin{abstract}
A preliminary survey of lichen diversity in the sub-alpine and alpine ecosystem of Kailash and its environs in upper Bhaderwah region of $J \& K$ state has revealed the occurrence of 17 species belonging to 11 families and 15 genera. Parmaliaceae has been recorded as the largest family with 4 species and 4 genera and is followed by Verrucariaceae and Cladoniaceae, each with 2 species and 1 genus. Foliose lichens are dominating the area and are represented by 8 species while crustose are represented by 4 species only. Both, corticolous and saxicolous lichen are represented by 8 species each while 1 species belonged to terricolous group of lichen.
\end{abstract}

Keywords: Bhaderwah, Kailash, Lichens, Parmaliaceae, Sub-alpine and Alpine region

\section{Introduction}

Lichen is an outstandingly successful group of organisms exploiting a wide range of habitats due to symbiotic association between a fungus and an algal partner that helps the organism to survive in varied climatic conditions and micro-habitats. In the world, about 13,000 species of lichens are recognized and this number rises to 20,000 if the orphaned species are also considered (Sipman and Aptroot, 2001) and about 2300 species have been reported from India (Singh \& Sinha, 2010; Nayaka et al., 2011). Himalayan region of India is rich in lichen biodiversity which constitute a very important part of cryptogamic vegetation in alpine habitats (Upreti, 1998). Jammu and Kashmir has varied climatic and physiographic conditions that provide different types of habitat for the growth of lichens. However, literature available for lichens from the state has revealed the occurrence of only 357 species of lichen belonging to 86 genera and distributed among 33 families (Awasthi and Singh, 1970; Priyadarshini 2006; Sheikh et al., 2009; Kumar et al., 2012; Sheikh et al., 2013). The present study area i.e. Kailash and its environs in upper Bhaderwah (longitude $74^{0} 10^{\prime} \mathrm{E}$ and $75^{\circ} 40^{\prime} \mathrm{E}$ and latitude $33^{\circ} 07^{\prime} \mathrm{N}$ and $32^{\circ} 52^{\prime} \mathrm{N}$ ) have an

\section{Author's Address}

${ }^{1}$ Department of Environmental Sciences, University of Jammu, Jammu, India

${ }^{2}$ Lichenology Laboratory, Biodiversity and Conservation Division, NBRI (CSIR), Lucknow

Email: anilkraina@yahoo.com altitudinal gradient from $1500 \mathrm{~m}$ asl (at Bhaderwah valley) to $3900 \mathrm{~m}$ (at Kailash kund). The climate and vegetation is of temperate type, represented by Pinus wallichiana, Cedrus deodara, Abies pindrow, Betula utilis and Juniper communis etc. Kailash (Kaplash) lake, at an altitude of about 3900m asl, is of religious importance for the local residents of Bhaderwah and of neighboring state of Himachal Pradesh.

\section{Materials and Method}

Lichens were randomly collected from all the available substrates (i.e. rocks, trees and soil) and details of locality, substratum and altitude were recorded. Altitude was measured with a GPS (Garmin GPS map 60CSx). Collected lichen samples were examined and identified at Lichenology Laboratory, National Botanical Research Institute, Lucknow, Uttar Pradesh, India. Specimens were identified by studying the morphology, anatomy and chemistry. Identification at the species level was carried out morphoanatomically using a stereomicroscope and light microscope and chemically with the help of spot tests, UV light and standardized thin-layer chromatography (Elix et al. 1993). The recent literature was consulted for identification of lichen taxa (Awasthi, 1988, 1991, 2000; Upreti, 1988; 1998). 


\section{Results and Discussion}

The lichens species collected in the preliminary survey along with their families, growth forms and their substratum of occurrence has been presented in table 1 . The perusal of table revealed the occurrence of 17 lichen species belonging to 11 families and 15 genera from the study area. Parmaliaceae has been recorded as the largest family (4 species and 4 genera) followed by Verrucariaceae and Cladoniaceae (both with 2 species and 1 genus each). Foliose lichens are dominant growth form represented by 8 species followed by crustose growth form (4 species), fruticose and squamulose (2 species each) and leprose growth form with one species only.

Table 1: List of lichens enumerated from the study area, their families, substratum and growth forms

\begin{tabular}{|r|l|l|l|l|}
\hline S.No. & Lichen Taxa & Family & Substratum & Growth form \\
\hline 1. & Anaptychia sp. & Physiaceae & Corticolous & Foliose \\
\hline 2. & Chaenotheca sp & Coniocybaceae & Corticolous & Leprose \\
\hline 3. & Cladonia fimbriata (L.) Fr. & Cladoniaceae & Corticolous & Squamolose \\
\hline 4. & Cladonia sp & Cladoniaceae & Corticolous & Squamolose \\
\hline 5. & Dermatocarpon miniatum(L.) Mann & Verrucariaceae & Saxicolous & Foliose \\
\hline 6. & $\begin{array}{l}\text { Lecanora muralis } \\
\text { var.muralis(schreber)Rabenh }\end{array}$ & Lecanoraceae & Corticolous & Crustose \\
\hline 7. & Leptogium sp & Collemataceae & Saxicolous & Foliose \\
\hline 8. & Lichinella cribellifera (Nyl.) Henssen & Lichinaceae & Saxicolous & Foliose \\
\hline 9. & $\begin{array}{l}\text { Lobothallina praeradiosa (Nyl.) Poelt } \\
\text { \& Leuckert }\end{array}$ & Megasporaceae & Saxicolous & Crustose \\
\hline 10. & Peltigera sp & Peltigeraceae & Saxicolous & Foliose \\
\hline 11. & Psora decipiens (Hedwing) Hoffm. & Psoraceae & Terricolous & Foliose \\
\hline 12. & Punctelia sp & Parmeliaceae & Corticolous & Crustose \\
\hline 13. & Rhizocarpon geographicum (L.) DC & Rhizocarpeaceae & Saxicolous & Crustose \\
\hline 14. & Usnea longissima Ach. & Parmeliaceae & Corticolous & Fruticose \\
\hline 15. & Usnea sp & Parmeliaceae & Corticolous & Fruticose \\
\hline 16. & Xanthoparmelia sp. & Parmeliaceae & Saxicolous & Foliose \\
\hline 17. & Xanthoria elegans (Link) Th. Fr. & Teloschistaceae & Saxicolous & Foliose \\
\hline
\end{tabular}

Both corticolous (present on barks of the plants) and saxicolous lichens (present on rocks) are represented by 8 species each, while terricolous lichen (growing on soil) is represented by one species only. High altitude of the study area with luxuriant vegetation represented by tree species like Pinus wallichiana, Cedrus deodara, and Betula utilis ('Bhojpatra') provide a good habitat for lichen growth. The area around the Kailash 'Kund' (lake) is devoid of any vegetation but large boulders and rocks provide a substratum for lichen growth. These rocks are covered with the lichen species Rhizocarpon geographicum (L.) DC giving a greenish- yellow colour to the surroundings which otherwise gives a barren look. This particular lichen species is very important as it can be used for lichenometric studies.

\section{Conclusion}

The area supports a rich diversity of lichens as evident from the fact that 17 species enumerated from the study area belonged to 15 different families and there is further scope for extensive exploration for lichens in the study area.

\section{Acknowledgement}

The authors are thankful to Director, National Botanical Research Institute, Lucknow for providing necessary laboratory facilities.

\section{References}

Ahti T. 2000. Cladoniaceae. Flora Neotropica Monograph 78. The New York Botanical Garden Press, New York, USA.

Awasthi D.D. 1988. A key to the macrolichens of India and Nepal. Journal of the Hattori Botanical Laboratory 65: 207-302. 
Awasthi D.D. 1991. A key to the macrolichens of India, Nepal and Srilanka. Bibliotheca Lichenologica (Suppl.) 40: 1337.

Awasthi D.D. 2000. Lichenology in Indian Subcontinent. Dehradun: Bishen Singh Mahendrapal Singh.

Awasthi D.D and Singh K.P. 1970. A note on lichens of Kashmir Curr. Sci. 39: 441-442.

Elix J.E. and Ernst-Russel K.D. 1993. A Catalogue of Standardized Thin Layer Chromatographic Data and Biosynthetic Relationships for Lichen Substances. 2nd edn. Australian National University, Canberra, Australia.

Hale M.E. 1974. The Biology of Lichens. 2nd edn. London:Edward Arnold, pp 303.

Hawksworth, D.L. and Hill D.J. 1984. The Lichen-forming Fungi. Glasgow: Blackie, pp 158.

Kumar,J., Khare,R., Rai,H., Upreti, D. K., Tayade, A., Hota1, S. , Chaurasia1, O. P. and Srivastava, R. B. 2012. Diversity of lichens along altitudinal and land use gradients in the Trans Himalayan cold desert of Ladakh. Nature and Science, 10 (4).

Nayaka, S. and Upreti, D.K. 2011. An Inventory of Lichens in Uttar Pradesh through Bibliographic Compilation. National Conference on Earth's Living Treasure , Uttar Pradesh State Biodiversity Board.
Priyadarshini. 2006. Ecological and taxonomic studies of lichens of Kalidhar forest range, Jammu. MPhil Dissertation submitted to University of Jammu, Jammu.

Sheikh, M.A. 2009. Taxonomic and ecological studies on Lichens of some forest sites of Jammu and Kashmir. PhD Thesis submitted to the University of Jammu, Jammu.

Sheikh, M.A., Raina , A.K. and Upreti, D.K. 2009. Lichen flora of Surinsar- Mansar wildlife sanctuary, J\&K. J. Appl. and Nat. Sci. 1(1): 79-81.

Sheikh, M.A., Raina , A.K. and Upreti, D.K. 2013. A preliminary observation of lichen flora in three districts of Jammu and Kashmir. International Journal of Current Research 5(4): 966-968.

Singh K.P. and Sinha G.P. 2010. Indian lichens: an annotated checklist. Govt. of India, Botanical Survey of India. Ministry of Environment and Forest, India, pp 571.

Sipman, H.J.M. and Aptroot, A. 2001 . Where are the missing lichens? Mycol. Res. 105: 1433-1439.

Upreti, D.K. 1988 . A new species of lichen genus Phylliscum from India. Curr. Sci., 57(6): 906-907.

Upreti, D.K. 1998 .Diversity of Lichens in India, In Perspectives in Environment (eds.Agarwal S.K., Kaushik J.P., Kaul K.K., and Jain A.K.),APH Publishing Corporation, New Delhi,pp 71-79. 